\title{
EVDEN ATÖLYEYE, ATÖLYEDEN FABRİKAYA ETNOGRAFIK BİR ÇALIŞMA: DEVREK BASTONU ÖRNEĞİ
}

\author{
Adem SAĞIR * \\ Semih KURTKARA**
}

Öz

$\mathrm{Bu}$ çalışmanın amacı sanayileşmeyle değișen üretim süreçlerinin geleneksel meslekleri nasıl etkilediğini göstermektir. $\mathrm{Bu}$ bağlamda odağına Devrek Bastonu'nu yerleştiren çalışma, sanayileşmenin toplumsal değişmelerle ilişkisini, bastonun dönüşüm hikayesiyle birleştirmiştir. Geleneksel mesleklerin makine karşısında direncini kaybettiğini varsayan çalışma, modern üretim sisteminin beslediği tüketim toplumu içerisinde nesneleşmelerine vurgu yapmıştır. Devrek Bastonu'nun atölyeden fabrikaya geçiş süreci nesneleşmenin sonucu olarak düşünülmüştür. Daha fazla kar güdüsü ve işin getirdiği maliyeti azaltma kaygısı "kızılcık ağacından yapılma" bastonu, odundan yapılan bir "tahtaya" dönüştürmüştür. Tahtaya dönüşen baston, üzerinde ustanın ürettiği bütün anlamlı pratikleri de kaybetmiştir. Çalışmada nitel araştırma deseni kullanılmıştır. Devrek'te 10 baston ustasıyla görüşmeler yapılmıştır. Veriler, "sorunlar ve mesleğin anlamlandırılması", "makineleşmenin bastonculuk kültürü üzerine etkisinin keşfedilmesi" ve "mesleğin gelecek kuşaklara aktarılması güçlüğü" şeklinde üç temel başlıkta çözümlenmiştir. Çalışmada makineleşmenin bastonun değerini düşürdüğü ve turistik bir metaya dönüştürdüğü ulaşılan önemli bir sonuç olmuştur.

Anahtar Kelimeler: Toplumsal Değişme, Makineleşme, Kültür, Meslek, Devrek Bastonu.

*Doç. Dr. Adem SAĞIR, Karabük Üniversitesi Edebiyat Fakültesi Sosyoloji Bölümü Mail: ademsagir@karabuk.edu.tr, ORCID: 0000-0003-0763-0518

**Yüksek Lisans Öğrencisi, Karabük Üniversitesi Sosyal Bilimler Enstitüsü Sosyoloji Ana Bilim Dalı, Mail: semihkurtkara@hotmail.com, ORCID: 0000-0001-7680-8725 


\title{
An Ethnographic Study from Home to Workshop, From Workshop to Factory: Case of Devrek Canes
}

\begin{abstract}
This study aims to determine how production processes that change with industrialization effect the traditional profession. In this context, the study, which has placed the Devrek Walking Stick in its focus, combined the relationship of industrialization with social changes with the transformation story of the walking stick. The study, which assumes that traditional professions have lost their resistance against the machine, emphasized their objectification within the consumer society supported by the modern production system. The transition process of the Devrek Walking Stick from the workshop to the factory was considered as the result of objectification. Increased profit motive and anxiety to reduce the cost of the work turned the "dogwood tree" cane into a "wooden board" made of tree. The walking stick, which turned into a wooden board, has lost all the meaningful practices produced by the master. The qualitative research design was used in the study. Interviews were made with 10 walking stick masters in Zonguldak/Devrek. The data are analyzed under three main headings: "Problems and interpretation of the profession", "discovering the effect of mechanization on the culture of the walking stick" and "difficulty of transferring the profession to the next generations." In the study, it was an important result that mechanization reduced the value of the walking stick and turned it into a touristic commodity.
\end{abstract}

Keywords: Social Change, Mechanization, Cultural, Work, Devrek Walking Stick.

\section{Giriş}

Makinelerin yükseldiği bir çağda yaşıyor olmanın insana verdiği his, kendisini tam olarak nereye konumlandıracağını kestirememezliktir. Bu aynı zamanda modern dönemde makinelere duyulan inancın yerini güvensizliğe bırakmasıdır. Güvenin sarsılmasında toplumsal alanın karşılaștığı hızlı değişimlerin baskın bir etkisi bulunmaktadır. Toplumsal değişme, gündelik hayatın kazandığı akışkanlık içerisinde metaların sabitliklerinin ortadan kalkmasını ifade etmekle birlikte zaman ve mekân ilişkileri üzerinde oluşan baskıyı da ifade etmektedir. Çünkü değişme kavramı, gündelik 
hayattaki alışkanlıkları dönüştüren ve inşa eden bir çerçeveyi içerisinde barındırmaktadır. Modern dünyanın makineye yüklediği anlamın kusursuzlukla bezenmiş doğası, günümüzde gündelik hayatı sunileștirmiştir. Bugün bahsi geçen dönüşümleri açılama noktasında küreselleşme kavramsal olarak gücünü korumaya devam etmektedir. Küreselleşme bu bağlamda toplumsal değișmenin hızını ve yönünü belirleyen sürecin kendisine gönderme yapmaktadır. Küreselleşmenin görünür etkileri dikkate alındığında sıklıkla ekonomik alanla ilişkilendirilmekle birlikte kavramın siyasi ve teknolojik boyutu oldukça güçlü durmaktadır (Talas vd. 2007, 151152). Bu bağlamda küreselleşme hem bilimsel gelişmelerin hızlanmasını hem de teknolojik değişimleri popüler hale getiren ana unsur olarak ortaya çıkmıştır. Bu noktada altı çizilmesi gereken temel konulardan biri yaşanan değişimlere karşı topluluk üyelerinin vermiş olduğu tepkilerdir. Bu tepkilerin biçimi "uyum" şeklinde olabileceği gibi "direnç" şeklinde de ortaya çıkabilmektedir (Sağır, 2016, 28). Değişimlere uyum sağlamak, gündelik hayatın standartlaşmasına neden olurken, direnmek ise anomi durumların ortaya çıkışına kaynaklık edebilmektedir. Ancak topluluk üyeleri sıklıkla uyum sağlamayı tercih etmekte ve uyumun getireceği güvenlikli/korunaklı alana teslim olmaktadırlar.

Toplumsal değişmenin kendisi insanlık tarihi kadar eski olmakla birlikte değişimin yönü, hızı ve niteliği toplumsal şartlara göre şekillenmektedir. Bugün gerçekleşen değişimlerin merkezinde makinelerin oluşu, aynı zamanda toplumun bütün alt parçalarının da onlar tarafından şekillenmesine kaynaklık etmektedir. Bugünün insanı, üretimden siyasete, aileden toplumsal ilişkilere kadar pek çok alanın makineler tarafından dönüştürüldüğü bir sürecin merkezinde yaşamaktadır. Sanayi Çağı'nın dikkat çekici yönü teknolojiyi üretebilme ve teknolojiyi yönetebilme becerisi olmuştur. Koçak’a göre (2016) üretim ilişkilerinde makinenin merkeze yerleşmesi insanlık tarihini kökten değiștirmiş, insanın işe ve dünyaya bakışını 
da yeninden inşa etmiştir. Sanayileşme ve küreselleşme arasındaki uyumlu ilişkiler teknolojinin sürekli yenilediği bir dünya algısıyla paralel ilerlemektedir. Küreselleşmenin kapitalist çizgiler etrafında pazar kavramını yeniden yapılandırarak tüm dünyayı etkisi altına alan bir yönü bulunmaktadır. $\mathrm{Bu}$ yön, küreselleşmenin piyasalaştırdığı sosyal, kültürel ve ekonomik hayatın kendisine de gönderme yapmaktadır. Küreselleşmenin ekonomik tarafında üretimin yaşamış olduğu değişimlere özellikle değinmek gerekir ki bu çalışmanın çıkış noktası da burada şekillenmiştir. Günümüzde, geleneksel olarak nitelendirilen "ulus-devlet" temelindeki yapının aksine, üretimler küresel çerçevede yapılmakta, üretimin farklı aşamaları farklı coğrafyalarda sonuçlandırılmaktadır (Bayar, 2008, 28).

Sanayileşme başlı başına kültürel ve sosyal açıdan insanların değişim ve dönüşüm içinde olduğu bir gerçekliği ortaya çıkarmaktadır. Değişen kültürler, sosyal ilişkiler ve farklı mekanlara geçiş süreci tam olarak sanayileşmenin bir ürünü olarak gündelik hayata dahil olan parçalardır. Tarımsal faaliyetten kopuş süreci insan hayatının mekân ile olan bağının kopmasına neden olmaktadır. Nitekim bu kopuş geleneksel yaşantının kodlarının da olumsuz yönde çözülmesine neden olmaktadır. Sanayileşmeyle birlikte ortaya çıkan mesleki hayat ve üretim tarzları sanayileşme öncesi mesleki üretim formlarına kıyasla farklı bir hal almış ve çalışma normları değişime uğramıştır. İnsanların, yeni ekonomi olarak adlandırılan sanayileşme sonrası ekonomi anlayışında yaptıkları, icra ettikleri çalışmaların süreleri de oldukça uzun zaman alsa da el emeğinden oldukça uzak bir vaziyettedir (Sennett, 2006, 53). Zanaat kavramı sanayileşme sonrası yeni ekonomi çerçevesinden ele alındığında görünürlüğünü kaybetmeye ve zanaatkarlar da bu bağlamda popülerliklerini yitirmeye başlamışlardır. El emeği ile işlenen ürünlerin yerini fabrikasyon ürünler almış aynı şekilde zanaatkarların üretim alanları olan atölyelerin yerini ise makinelerin olduğu fabrikalar almıştır. Sanayileşme, alışılagelmiş çalışma standartlarında büyük değişimler ortaya çıkarmış ve geçmiş dönemlere ait çalışma prensiplerine $190 \quad$ Akademik Incelemeler Dergisi Cilt 15 - Sayı 1 (Nisan 2020) 
geçerliliğini kaybettirmiştir. Bunun yansıması olarak da değişen ve dönüşen üretim tarzlarını sanayi eksenli mesleki anlayışın merkezine yerleştirmiştir. Sanayileşme ekseninde değișen üretim modelleri kültürel geleneklerin de değişmesine neden olmuş ve insanın geçmişiyle arasındaki tarihsel bağ/aidiyet duygusunu sarsmıştır.

Türkiye'de sanayileşme kavramı küresel üretim bağlamında makineleşme ile paralel ilerlemektedir. Dünya üzerinde yaşanan standartlaşma ve makineleşme, işin yapılma biçimlerini değiştirmiş, geleneksel el işi ürünleri yerini makine ürünlerine bırakmıștır. $\mathrm{Bu}$ çalışmanın ortaya çıkış kaygısını da baston ve baston üreticiliğinin makineleşmeden zarar gördüğünün hikayesinin izlerini sürmek oluşturmuştur. Baston, Devrek örneğinde ele alındığında geleneksel bağları sürdürmek ve aidiyet duygusunun yaşatılması çerçevesinde düşünüldüğünde önemli bir özelliğe sahiptir. Baston yapımı ve baston ustalığının temelinde "marangozluk" sanatının olduğunu söylemek mümkündür. Marangozluk ve ağaç işlemeciliği baston üretiminde önemli bir noktaya karşılık gelmektedir. Ancak el yapımı baston üretiminin modern dönemde sanayileşme ve fabrikasyon ürünlere karşılık verememesinden kaynaklı olarak pazarlama konusunda sorunlar ortaya çıkmaktadır. Sennett'e (2006) göre bu sorunların en temeline inildiğinde ve toplumsal açıdan irdelendiğinde karşımıza motivasyon düşüklüğü ve sanayi ürünleriyle baş edememe durumu çıkmaktadır. Bütün bunlara el emeğinin anlamsızlaşması ve zanaatkarlık fikrinin değerini kaybetmesi eşlik etmektedir. Üretim, pazarlama ve satış sürecinde ortaya çlkan sorunlar da bastonculuğun geleneksel bir iş olarak sürdürülmesini kesintiye uğratmakta ve baston üreticilerinin geçimlerini sağlayan bir iş olmaktan çıkmaktadır.

Hazırlanmış olan bu çalışmanın odağında Zonguldak'a bağlı Devrek ilçesinde bastonculuk mesleği bulunmaktadır. Çalışmanın amacı kaybolmaya yüz tutmuş bir mesleğe atıf yaparak son ustaların 
dilinden bir kayboluş hikayesini metinleştirmektir. Zonguldak, Osmanlı Devleti'nden Türkiye Cumhuriyeti'ne maden kenti olmuştur. Bununla birlikte Türkiye'nin sanayileşmesine hammadde ve zihinsel emek bağlamında besleyici öğeler sunmuştur. Ancak uzun bir süredir sürekli göç veren ve istihdam alanlarının azaldığı bir kent olarak Batı Karadeniz'in küçülen sanayi kentlerinden birisine dönüşmüştür. Devrek'in ve bastonculuğun da hem Türkiye Cumhuriyeti'nin kuruluş sürecine götüren bir hikayesi hem de Zonguldak'ın gerileyişinden kendine düşen payı alan bir yönü de bulunmaktadır. Bu bağlamdan hareket edildiğinde Devrek için kültürel belleğin korun(a)madığı bir mekân olma özelliğine sahip olduğunu ileri sürmek yanıltıcı olmasa gerektir. Devrek ve Devrek'e ait kültür, tıpkı Batı Karadeniz'de yer alan birçok tarihsel alan gibi yüzer-gezer bir parça olarak köklerinden sarsılmıştır. Devrek için kıyıda kalmışlık, kültürel belleğin sürdürülmesinde tek başına kalmışlı̆̆ı ifade etmektedir. Akışkan dünyada standartlaşmaya ve neo-liberal dönüşümlere teslim olan bir yerdir. Böylece belleği korunamamış bir yerde kaybolan kültürel pratiklerin silinme hikayesinin izlerini süren bu çalışma, yaşamın kıyısındaki bir kültürün hikayesini görselleştirmektedir. Nesne olarak bastonun makineyle girdiği temasta dönüşümün ve sıradanlaşmanın tekdüzeliğini betimleyen bu çalışma, el işi doğallığının yerine makine işinin yerleștirilmesinin bastonun otobiyografisiyle özdeşleştirerek betimsel bir anlatı kurma yolunu seçmiştir. Ustaların zihinsel becerileri sabit kalırken ve ustalar yeteneklerini koruyabilirken, bir iş nesnesi olarak bastonla kurduğu etkileşim piyasanın baskısından kendi payına düşeni almaktadır. $\mathrm{Bu}$ bağlamda çalışmada mesleği bitiren temel etkenlerin neler olduğunu saptamak ve analiz etmek önemli kabul edilmiştir. Ayrıca çalışmada nitel araştırma deseni kullanılmış ve bu işin içinde yer alan ustalarla mülakatlar gerçekleştirilmiştir. Dolayısıyla çalışma aslında bastonun ve bastonculuğun gözünden nesnenin değișim ve dönüşüm hikayesidir. Burada ustanın bastonun dili ve gözü olduğu kabulü, metaforik olarak bastona atfedilmiştir. 


\section{Bastonun Tarihçesi}

Baston çok uzun yıllar boyunca görme engelliler tarafından kullanılmış bir araçtır. Bugün baston olarak bildiğimiz şeyi kaza sonucu gözlerini kaybeden İngiliz gazeteci James Biggs 1921 yllında geliştirmiştir. Motorlu taşıt sürücülerinin kendisini görebilmesi için bastonu beyaza boyamıştır. 1931 yılına kadar "beyaz baston" toplum tarafından kabul gören bir uygulama olarak dikkat çekmemiştir. Şubat 1931'de Fransa'da Guilly D'herbemont adlı bir kişi ilk defa görme engellilerin katılım sağladığı "ulusal beyaz baston" hareketi olarak bir kampanya başlatmıştır. Mayıs 1931 yılında BBC radyosu beyaz bastonun ulusal bir sembol olarak kullanılmasını önermiş̦tir. Amerikan Ulusal Körler Federasyonu 6 Temmuz 1963 genel kurul toplantısında 15 Ekim'in bütün eyaletlerce “Beyaz Baston Güvenlik Günü” olarak kutlanmasını kararlaştırmıştır. Dünya Beyaz Baston ve Güvenlik Günü 1970 yılında Uluslararası Körler Federasyonu tarafından kabul ve ilan edilmiştir (Köseler, 2019)

Tarihsel süreç boyunca, farklı baston türleri kültürlerin gerek gündelik hayatlarında gerekse toplumsal hayat statülerinin halini almıştır. Eski Mısır'da baston kullanımı kölelere yasaklanmış sadece özgür olan insanların baston kullanmalarına izin verilmiştir. Baston kullanımı zorunluluktan ortaya çıkmıştır ve ilk kullanım zamanlarında sıradan bir sopa olarak kullanılırken ilerleyen dönemlerde daha seçici davranılmış ve yapım aşamasında sert ve hafif ağaçlar kullanılmaya başlanmıştır. 11. Yüzyılda Fransa sokaklarında kadınlar, koltuklarının altına yerleştirdikleri ince tipte bastonlarla görülmeye başlanmışlardır. Yaşadığı dönemin moda ikonu olan Fransız kraliçesi Marie Antoinette'nin elinde dikkat çeken baston, diğer soylu kadınlar içinde önemli bir aksesuar olarak yaygınlaşmıştır (Yalın, 2019).

Yolcular, savaşçılar, çobanlar tarafından çok farklı amaçlarla kullanılan asa sembol olarak da çok önemli bir yere sahiptir. Yolcular 
için yürüme ve destek aracl, çobanlar için hayvan otlatma aracı, din adamları için güç vasıtası, kral ve hükümdarlar içinse kudret göstergesi olarak kabul görmektedir. Eski Çin'de asa kötülüklerin kovulması amacıyla kullanılmaktadır. Hz. Musa'ya, Allah tarafindan peygamber olarak görevlendirildiğine dair bir alâmet olmak üzere asa mucizesinin verildiği belirtilmektedir. Buna göre Hz. Musa'nın elindeki asa önce yılana dönüşür, sonra da eski haline gelir. İsrailoğulları çölde susuzluktan şikâyet edince rab Hz. Musa'dan, "ırmağa vurduğu değneği alarak kayaya vurmasını" ister ve kayadan su fişkırır. Hadislerde asa kelimesi, çeşitli işlerde kullanılan bir gereç olması yanında, Hz. Musa'nın mucizeli değneği anlamında da kullanılmıştır (TDV İslam Ansiklopedisi, 1991).

Devrek bastonu üretildiği ilk günden itibaren asaletin ve gücün simgesi olarak atfedilmektedir. Bu bağlamda yüksek makamlarda yer alan devlet adamlarına hediye olarak verilmesiyle birlikte Devrek Bastonunun popülerliği gerek Türkiye gerekse dünya genelinde yaygın hale gelmiştir. Devrek bastonculuğu babadan oğula, ustadan çırağa geçerek günümüze kadar gelmiştir. Devrek bastonculuğu işletmeciliği 18. yüzyıllara dayanmaktadır. 1980’li yıllarda Münteka Çelebi usta Devrek bastonu imalatına başlamış ve Devrek bastonu kendi motifleri ile ön plana çıkmıştır. 1933 yılında Zonguldak'ta düzenlenen tasarruf ve yerli malı haftasında Aziz Salman ustanın bastonlarını sergilemesiyle geniş bir topluluğa hitap edecek biçimde yöre dışına ilk çıkışını yapmıştır ve Devrek'te bastonculuğun tarihi de böyle başlamıştır (Özcan, 2016, 10). Devrek Bastonu festivaller hariç 1994 yılı içerisinde Kültür Bakanlığının desteğiyle Ankara ve Topkapı Sarayında düzenlenen sergilerde tanıtılmıştır. Birçok Üniversitede de Devrek Baston sanatı ile ilgili seminerler düzenlenmiştir. Yurt içi ve Yurtdışı Festival ve Fuarlara davet edilmiştir. Bastonunun kitle iletişim araçlarında aksesuar olarak sunumu da dahil sembolik anlamlarla gösteriliyor olması konumunu etkilemektedir. 


\section{Mitoloji ile Devrek Bastonu İliş̧kisi}

Baston yapımının ortaya çıkış serüveni yılan ve ağaç benzerliğinden dayanmaktadır. Ağacın dalına sarılmış bir vaziyette bulunan yılan baston yapımını ortaya çıkaran bir etken olmuştur. $\mathrm{Bu}$ benzerlik durumu bir anlamiyla hayvan ve bitkilerin birlik halinde oldukları, diğer anlamıyla ise sağlıklı bir zıtlık anlamlarını içermektedir. Kuzeybatı Anadolu ve Batı Karadeniz Bölgesi, bitki örtülerinden kaynaklı olarak ağaç yönünden zengin ve el işçiliğinin çok yoğun olarak görüldüğü bölgeler olarak dikkat çekmektedir. İlk çağlardan itibaren ağaca dayalı el işçiliğinin bu bölgelerde aktif olarak süregeldiğini söylemek mümkündür (Sevin, 1944, 174). Devrek ormanlarında yer alan ağaçlardan birisi çam ağacı, Hititlerin kutsal olarak atfettiği metinlerinde yer almaktadır. Bu kutsal kabul edilen Hitit metinlerine göre çam ağaçları yaz-kış yapraklarını dökmediği için ölümsüzlükle sembolize edilmiştir (Tuncer, 1993, 139). İlkel dinlerde yılana tapınmalar söz konusudur. Nitekim MÖ Zeus'tan ayrı olarak halkın tapındığı, göğüsleri çıplak, elinde silah olarak yılan tutan bir ilahenin varlığı söz konusudur (Nadas, 1995). Nadas'ın da ifade ettiği gibi bölgenin mitolojik dinamikleri arasında yer alan "Altın Post" söylemiyle irtibat kurulabilmesi mümkündür. Kutsal emanetin gizli bir yerde ağaca asılarak saklanması ve bekçiliğinin bir yılan tarafından üstlenilmesi, binlerce yıllık bir tarihi anlatım olarak karşımıza çıkmaktadır. Yılan ilkçağlardan itibaren sağlıkla sembolize edilmiş, dolayısıyla da hekimliğin sembolü olarak görülmüștür. M.Ö. 400'de yapıldığı varsayılan Bergama Sağlık Yurdu'nun bulunduğu alanda bir anıt sütun mevcuttur. Sütundaki kabartmalarda dikkat çeken detay hamam tası ve kafalarını tasa sokmaya çalışan iki yılan göze çarpmaktadır. Yılan, hekimliğin ve sağlık tanrısı Asklepios'un ikinci simgesi sayılmıştır. Birinci simge tastır. Günümüzde de halen hekimlik ve eczacılığın sembolü olarak yılan kullanılmaktadır. Üçüncü simge ise yorgun hekimin dayanacağı bastondur. Baston hekimin ne denli yorgun olursa olsun hastasına 
ulaşmak zorunda olduğunu simgeler (Tuncer, 1993, 127; Yalın, 2019).



Görsel 1-2: Yılan Başlıklı Devrek Bastonları

Hekimliğin simgesi olan üç nesnenin Devrek ve Devrek Bastonuyla ilgili ortaya çıkan benzerliğin rastlantı olamayacağı açık bir şekilde ortadadır. Devrek su adı ya da su tası anlamına gelmektedir. Coğrafi konumu, yer adı ile örtüşmektedir. Bölgenin Gerede, Bolu, Kastamonu ve Safranbolu bașta olmak üzere, tıp biliminde büyük tıpçılara ve hekimlere ev sahipliği yaptığ bilinmektedir. Tüm bu detaylar bir araya getirildiğinde, Devrek Bastonu üzerinde yer alan yılan figürünün tarihsel bir yapıya sahip olduğu ve baston yapımının da yüzyıllar öncesine dayandığı ortaya çıkmaktadır (Çelikdönmez, 2000, 82).

\section{Devrek Bastonunun Dönüşümü: Asâ'dan Baston'a Giden Yolculuk}

Asâ; din adamlarının taşımış olduğu uzun oduna verilen isimdir. Asıl anlam olarak değnek olduğu bilinmektedir. Osmanlıca da uzun çomak olarak adlandırılan asânın Kamus-u Türki'de karşılık gelen anlamları ise şu şekilde dikkat çekmektedir. Asâ uzun el değneği, dayanılacak uzun sopa anlamına geldiği gibi genellikle başı topuzlu veya kancalı, gümüş ve altınla süslenmiş özellikleriyle de 
şekillenmektedir. Ayrıca asâ bazı millet ve topluluklarda siyasi ve dini başkanlığın alameti kabul edilmekte ve kullanılmaktadır (Pakalın, 1993, 91).

1889 tarihli Kastamonu Salnamesi'nde yer alan bilgilere göre; Devrek'te ceviz ağacından yapılan ürünler çok fazla rağbet görmektedir. Devrek Bastonunun 17. yüzyldan itibaren popülaritesinin artmasının asıl nedeni Osmanlı Devleti'nin yaşadığı toplumsal ve kültürel değişimlerdir. Tanzimat Fermanının ardından değişim gösteren kılık kıyafet düzenlerinin ardından fesle birlikte bastonda klyafetleri tamamlayan bir aksesuar olarak dikkat çekmektedir. Bu sebepten kaynaklı olarak bastonlar yapılmaya başlanmıştır (Arseven, 1983, 182). Münteka Çelebi'ye $(1994,111)$ göre, Cumhuriyet öncesi Devrek'te baston yapımının savaşlar nedeniyle bir ara duraklamıştır. Yemen İsyanı, I. Dünya Savaşı ve ardından İstiklal Savaşı'nın başlamasını takiben ilan edilen seferberlik emirleri doğrultusunda silah altına alınan Devrekli baston ustalarının 10 yl kadar memleketlerine gelemediklerinden bahseden Münteka Çelebi, baston üretiminin aksadığını vurgulamıştır. İstiklal Savaşı sonrasında, Devrek'e dönebilen baston ustalarının, Yemen Harbine gitmeden önce 3-4 liraya satabildikleri bastonlarını, 1 liraya dahi satamadıklarını iddia eden Çelebi; bunun doğal sonucu olarak baston ustalarının geçimlerini temin etmek için başka işlere yöneldiklerini söylemektedir. Araya giren ve yıkıcı bir etki yaratan 2 . Dünya Savaşı sonunda baston yapımında fetret sürecinin yaşandığını ve ustadan çırağa el verme geleneğinin son bulduğunu belirtmiştir. 


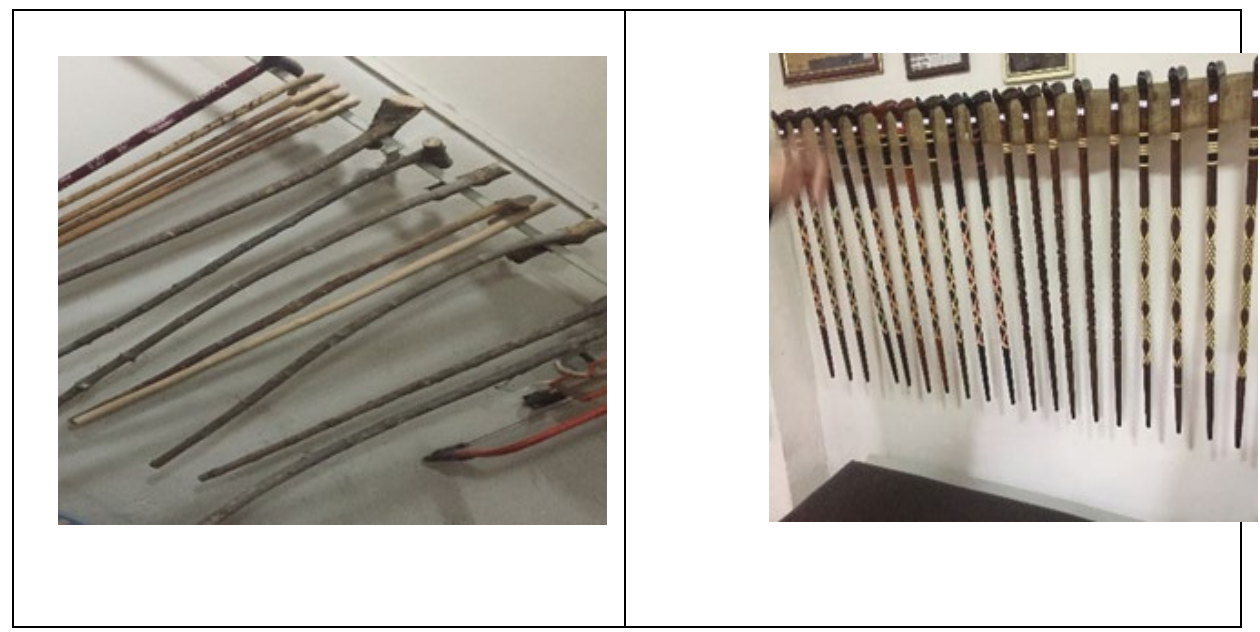

Görsel 3-4: Asâ'dan Baston'a

Kızılcık ağacından üretilen Devrek bastonunun yapım sürecine bakılacak olunursa birkaç aşamadan oluştuğunu söylemek mümkündür. İlk olarak kızılcık ağacı kesilmekte ve dalları ayıklanarak bir yıl kadar bekletilmektedir. Bir yıllık sürenin ardından düzeltilen dallar tornaya konularak bekleme süreleri devam etmektedir. Üç ay kadar daha bekletilen dallara, sapı ve pabucu takılarak işlenmeye başlanmaktadır. İşleme sırasında bastonu yapan ustanın kullanmış olduğu malzemeler ve kullandığı motiflere eklenen hayal gücüyle birlikte meşhur Devrek bastonlarının hepsi birbirinden farklı motiflere sahip olacak şekilde tasarlanmaktadır. Devrek Bastonunun kişiye özel olması aslında bu noktadan ortaya çıkmaktadır. Her ne kadar aynısı yapılmak istense de birebir aynı tasarım ikinci kere yapılamamaktadır. $\mathrm{Bu}$ işlemlerden sonra renk verme işlemine geçilmektedir. Devrek Bastonunu dünyaya tanıtan en dikkat çekici özelliği tamamen el işçiliğine dayanmasından kaynaklanmaktadır. Türkiye ve Dünya genelinde yapılan diğer baston çeşitlerinde el işçiliği sadece sap kısımlarında uygulanmaktadır. Devrek Bastonunda ise gövde kısmı çok ince bir işçilikle işlenmektedir. Pabuç kısmında kaymaları önlemek ve sabitlik kazandırmak amacıyla manda boynuzu kullanılmaktadır. Manda boynuzunun bir başka özelliği ise hijyenik olması ve sokaktaki 
mikrobik bakterileri üzerinde taşımamasından kaynaklanmaktadır (https://www.ismek.ist/blog/icerik.aspx?p=1228 e.t: 12.01.2019).

\subsection{Devrek Bastonunun Bugünü}

Gelenekler ve kültürel faaliyetlerin halkalarını oluşturan en önemli dinamik el işçiliğiyle ortaya koyulan ürünlerdir. Devrek Bastonuyla alakalı en eski bilgiler, 1892 tarihli Kastamonu salnamesinde bulunmaktadır. Bu kaynağa göre Devrek Bastonu zanaat dalında yer almaktadır (Çelikdönmez vd. 2009, 56). Baston yapımının Devrek ile özdeşleşmesinde farklı kabul ve görüşler vardır. Bunlardan ilki Devrek'te marangoz olan Ali Ziya adlı bir Osmanlı askerinin İngilizlere esir düşmesi neticesinde baston yapımını öğrendiği ve dönüşünde bu sanatı Devrek'te icra etmesiyle başladığı görüşüdür. Bir diğer görüş ise orman yönünden zengin bir coğrafya olan Devrek'te baston yapımının Ali Ziya Efendi'den önce de mevcut olduğudur ki Kastamonu salnamesinde Devrek'ten söz edilirken baston yapıldığı belirtilir. Devrek'te geçmişten bugüne ağaç işçiliği, oymacılık, sandıkçılık, semercilik, mobilyacılık gibi el sanatlarına dayalı kolların var olduğu göz önüne alınırsa, temelinde marangozluk sanatı yatan baston yapımının burada temellenip gelişmesi bir rastlantı değildir. Devrek'in baston yapımında kullanılan kızılcık ağacı açısından zengin oluşu baston yapımı faaliyetinin en önemli etkilerinden biridir. Baston sanatında çoğunluk hayvan figürlerinden oluşmaktadır. Yılan ve at figürleri ise en dikkat çeken motiflerdendir. Devrek bastonu ustaları yılan figürünü hem sağlık açısından hem de kıvrım kıvrım olmasından dolayı kullandıklarını söylemektedirler. Hayvan figürlerinin yanında lale, papatya ve gül figürleri de kullanılmaktadır. Dünyanın sonsuzluğunu sembolize eden kare, dikdörtgen, üçgen, baklava, daire, çoban çentiği ve yıldız motifleri de çok sık rastlanan motifler arasındadır. Kimi zaman da baston ustalarının kendilerine özgü motifler işlediği görülmektedir (Teke vd. 2018, 97; Şahin, 2014, 271). Bastona işlenen farklı desen ve 
motiflerin geliştirilmesi süre açısından uzun bir zaman dilimini gerektirdiğinden oldukça zahmetli iștir. Özellikle görüşme yapılan ustaların da vurguladığı biçimde motif işinin ilhamla ilerlediğinin altını çizmek mümkündür.

Devrek bastonunun karşı karşıya kaldığı en mühim sorun baston sanatını ilerletebilecek çırakların yetişemiyor olması olarak belirtilmektedir. Devrekli ustalar bastonculuğun artık eskisi kadar değer görmediğini ve önceden insanların gerçek ustalara baston yaptırdıklarını; şimdi ise mesleği bilen bilmeyen herkesin usta olduğunu belirtmekte; usta-çırak ilişkisinin tamamen kaybolmaya yüz tutmaya başladığını ve bu mesleğin yok olup gitmesinden korktuklarını dile getirmektedirler (Teke vd. 2018, 98). Teke ve arkadaşlarının çalışmasında vurgulandığı gibi mesleğin devamını sağlayabilmek için yeni çırakların yetişmesi gerekmektedir. Bastonculuk mesleğinin asıl sorunu eğitim hataları ve zanaatkar sorunudur. Böylece eski ustaların baston yapım yöntem ve tekniklerini iyi bilen sanatkârlara ihtiyaç duyulduğuna vurgu yapmak önemlidir.

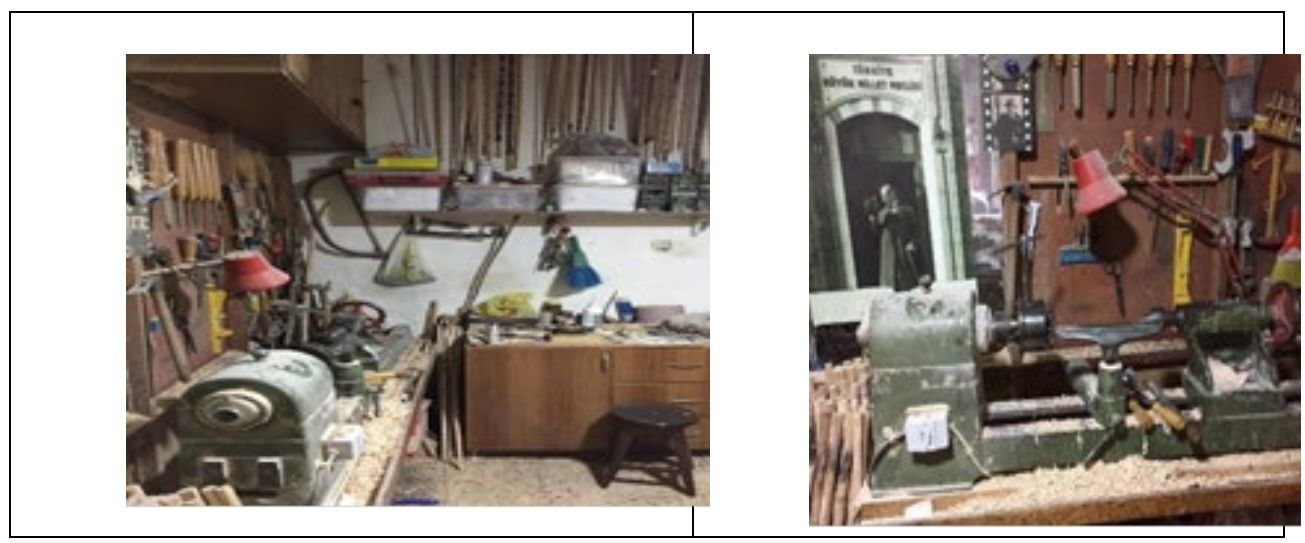

Görsel 5-6. Baston Yapımında Kullanılan Araçlar 


\section{Araştırmanın Metodolojisi}

Zonguldak orman ve ağaç bakımından oldukça zengin bir bölgede yer almaktadır. Yaklaşık olarak 540.000 hektara yakın ormanlık alana sahiptir. Ormanın içinde 254, ormanlık alanın yanında ise 269 adet köy bulunmaktadır. Orman ürünleri farklı işlevlerle de işlenebilmektedir. Devrek'te yer alan ve günümüz baz alındığında halen faaliyetlerini sürdüren bastoncular çarşısı Devrek açısından önemli bir kültürel kimlik inşası oluşturmaktadır. Lakin bölge sürekli göç vermeye başladığı için ormancılıkla ilgili çalışmalar ve ormancılık mesleğine olan ilgide 1980'lerden sonra fark edilir biçimde azalmalar oluşmuştur. Ayrıca orman ürünlerine olan ilginin azalmaya başlaması yine ormancılık mesleğinin sonunun geldiğini gösteren belirtilerden biri olarak dikkat çekmektedir. Baston kültürünü sona yaklaştıran etken sadece ormancılık mesleğinin bitmiş olması değil, ayrıca sanayi üretiminin de artış göstermesi önemli seviyede tehdit oluşturduğu saptanmıştır. Baston ustalarına ait olan çarşı ve halen burada üretime devam eden ustaların işleri, sanayi üretimi bastonların etkisiyle hem maddi hem de manevi anlamda değersizleşme sürecine girmiştir (Sağır, 2016, 38).

Bu çalışmanın temel kaygısı yaşanan sosyo-ekonomik, kültürel ve toplumsal değişimler dikkate alındığında Zonguldak/Devrek'te bastonculuğun sanayileşme sonrasında bu süreçten nasıl etkilendiğini saptayabilmek ve çözüme ulaştırabilmektir. Sanayileşmenin beraberinde getirdiği seri üretimin kültürel değişime olan etkisi ve varsa bu etkilerin meslekler üzerindeki etkilerini analiz edebilmek bu araştırmanın kaygılarından biridir. Ayrıca Cumhuriyet döneminde gelişim halinde olan meslek dallarının, günümüz şartlarında geri planda kalmasına neden olan ana sebeplerin neler olduğunu çözümleyebilmek bu çalışmanın en önemli hedeflerinden birisidir. Araştırmanın problemleri "Sanayileşme el işçiliği ve zanaatkarlı̆̆ı tamamen yok mu etmiştir?", "Makineleşme el emeğini 
nasıl dönüştürdü?”, "İşin devredildiği usta -çırak ilişkisinin azalması geleneksel baston yapımının kaybolmasını hızlandırdı mı?" şeklinde kurgulanmıştır.

Araştırmada nitel araştırma yöntemi kullanılmış, baston ustalarıyla mülakatlar gerçekleştirilmiştir. Çalışmanın kültürel bir alanı betimsel anlatılarla sunma kaygısı, etnografiye başvurulmasına kaynaklık eden neden olmuştur. Etnografi, bir insan grubunu ya da bir grubun kültürünü anlama ve betimleme için gösterilen bilimsel çabalar bütünüdür. Nitel düşünceye dayalı bu çabalar, araştırılan grup ya da kültürün bütününü, bileşenlerini, onların arasındaki ilişkileri, kültürün mensuplarının gözünden görüp onların kültür kodlarıyla açarak anlamayı içermektedir.

Etnografi, Boas, Malinowski, Radcliffe-Brown, ve Mead gibi antropolog tarafından yürütülen kültürel antropolojinin alt dalı olarak ortaya çıkmıştır. Etnografik araştırmalar, aynı kültürel değerleri taşıyan ve paylaşan toplulukların tümünün ya da alt kümelerinin eksiksiz bir biçimde betimlenmesi noktasına odaklanmaktadır. Etnografik araştırmaların odağında tanımlanması mümkün insan gruplarının sosyal davranışları yer almaktadır (Creswell, 2013, 91). Etnografik araştırmalar, araştırma kapsamındaki nesnenin gündelik hayat akışı içerisindeki rutinini açığa çıkarabilmek amacıyla yapılmaktadır. Etnografi, yaşamın akışkanlığı bağlamında gerek somut gerekse soyut ögeleri içermektedir. $\mathrm{Bu}$ noktada hem fiziksel davranışların çözümlenmesinde hem de duygu ve inanç gibi soyut öğelerin anlaşılmasına doğrudan katkı sağlaması nedeniyle önemlidir (Kartarı, 2017, 218). Creswell' e (2013) göre, etnografik araştırmaları önemli kılan temel kıstas, aynı kültür içerisinde yer alan toplulukların düşünce sistemlerinin nasıl işlediği, bu grupların nasıl çalıștığı ve nasıl hareketlendiklerinin analizini yapmaya katkı sağlamasıdır.

Araştırmada Devrek'te baston ustalığı yapan ve baston atölyesi 
olan 10 katılımcı ile derinlemesine görüşmeler yapılmıştır. Çalışmada baston ustalarının seçilmesindeki nedenleri, ilk elden veri toplama kaygısı, meslekle ilgili sorunların içerden bir gözle tanımlama çabası ve mesleğin nereye evrileceğine dair çıkarımlar bulma beklentisidir. Katılımcıların demografik bilgileri aşağıda yer alan tabloda belirtilmiştir;

Tablo 1. Katılımcıların Demografik Bilgileri

\begin{tabular}{lllll}
\hline K No & Yaş & K/E & Medeni Durum & Çalışma yılı \\
K1 & 46 & Erkek & Evli & 30 \\
K2 & 53 & Erkek & Evli & 40 \\
K3 & 42 & Kadın & Evli & 15 \\
K4 & 46 & Erkek & Evli & 25 \\
K5 & 52 & Erkek & Dul & 30 \\
K6 & 47 & Erkek & Evli & 33 \\
K7 & 43 & Kadın & Evli & 11 \\
K8 & 40 & Erkek & Evli & 20 \\
K9 & 46 & Erkek & Evli & 30 \\
K10 & 46 & Erkek & Evi & 32 \\
\hline
\end{tabular}

$\mathrm{Bu}$ araştırma kapsamında hazırlanmış mülakat soruları ve araştırmanın genel çerçevesi ile ilgili etik kurul başvurusu yapılmıștır. Sosyal ve Beşeri Bilimler Araştırmaları Etik Kurulu'nun 20.02.2020 tarihinde yapılan toplantısında 2020/03 nolu kararla çalışmanın yapılmasını etik kurula uygunluğu kabul edilmiştir.

\section{Araştırmanın Bulguları}

Çalışmada elde edilen veriler birkaç alt başlıkta toplanmıştır $\mathrm{Bu}$ alt başlıklarda dikkat çeken noktalardan ilk temel başlıklar "meslekte yaşanan zorlukların betimlenmesi, mesleği icra etme sebebi, bastonun tanınırlığı" olarak alt kategorilere ayrılmıştır. Sanayileşmenin el sanatlarını değersizleştirip değersizleştirmediği ve bastonun kuşaklara aktarılabilirliği diğer iki temel başlık olarak 
kullanılmıştır.

\subsection{Baston ve Bastonculuk Kültüründe Temel Sorunların Algılanma Biçimleri}

Katılımcılara yöneltilen " $\mathrm{Bu}$ meslekte geçmişten günümüze yaşadığınız zorluklar oldu mu” sorusu, makro boyutuyla geçmişten bugüne mesleğin geçirmiş olduğu evrimi hem ekonomik hem de iş tatmini anlamında değerlendirmek, diğer taraftan ustaların işleriyle ilişkili beklentilerinin karşılanıp karşılanamaması durumuna açıklık getirebilmek amaciyla sorulmuştur. Yöneltilen soruya; "Harcanan emek, materyal eksikliği ve sanayileşme" merkezli sorunları sıralayan katılımcı kendisini şu şekilde ifade etmiştir: "Yaşanan zorluklar olarak malzeme bulmada sıkıntılar çekilmesi, bir ürün ortaya çıkarabilmek için çok uzun süre emek harcanması ve belki de en önemlisi devlet yetkililerinin yardımcı olmamasını söyleyebilirim." Bir diğer katılımcı (K6) ise "Tabii, oldu. Birçok dönemde maddi açıdan zorlandığım oldu" ifadesini kullanmıştır. Katılımcıların yaptıkları işe ekonomik olarak değer yüklemeleri ve değerin beklentilerinin altında kalması bastonculuğun ekonomik olarak geçim aracı olmasını ortadan kaldırmaktadır. Ayrıca yapılan görüşmelerde elde edilen verilerde makineleşmeye ayak uyduramayan ustaların bu meslek içinde yavaşça "bastonlarıla birlikte kaybolacaklarına” inandıkları görülmüștür.

Devrek Bastonu yapımı uzun bir süreci kapsamaktadır. $\mathrm{Bu}$ bağlamda baston yapma kültürü, ciddi bir ön hazırlık, çok uzun bir süre ve sabır isteyen bir mesleki pratiğini ifade etmektedir. $\mathrm{Bu}$ durumu ön plana çıkaran katılımcıların değerendirmelerine bakıldığında K2 "Ahşap ve ormancılık malzeme temini için iki önemli etken. Ağaçla uğraşmak oldukça zahmetli bir iş. Hem zorluk hem de bu mesleğin ilerlemesi için ağaçla ve ormancılıkla uğraşmak önemli bir noktada yer alıyor" olmasına vurgu yaparken, bir başka katılımcının değerlendirmesi "illaki oldu, ağaç bulmakta zorlandım, baston yapmakta zorlandım, bastonların ticaretini yapmakta zorlandım" (K7) 
şeklinde olmuştur.

Baston ustalarının yakındığı diğer bir problem devletten yaptıkları işle ilgili destek görememeleri olmuştur. Ustalar ayrıca bastona gereken önemin verilmediği ve geleneksel mesleklerinin gittikçe yok olduğunu ifade ettikleri görülmüştür. El sanatlarını koruma altına almak yerine, makine yapımı bastonlara piyasada rahatlıkla ulaşılması ve reklamlarının yapılması, ustaların vefat etmesi ya da mesleği bırakmaları ve mesleği sürdürecek çırakların yetişememesi bastonculuğun gelmiş olduğu son durumu betimlemesi bağlamında dikkat çekmektedir. Emeğin gözetilmemesi ve zanaatkarlara sahip çıkılmaması noktasında katılımcılardan birisinin değerlendirmesi, "çok ucuz malzemelerle üretim yapılıyor. Emek geri planda kalıyor. Seri üretim daha cazip geliyor"(K3) iken, diğer bir katılımcı ise, "Oldu, işi öğrenmeye başladıktan sonra yaşadığım zorlukları aşmaya başladım"(K9) şeklinde olmuştur. Diğer bir katılımcı ise "Bize devlet yetkilileri tarafından hiç yardımcı olunmadı. Tamamen maddiyat ön planda ve ustalara gereken önem asla verilmiyor" (K5) diyerek tarihi devrek bastonunun yeterince desteklenmediğine vurgu yapmaktadır.

Geçmişten bugüne toplumsal ve ekonomik dönüşümlerin en yoğun etkilediği geleneksel mesleki alanların içerisinde yer alan baston işinde "sertifikasız" ve "vasıfsız" kişilerin sektör içinde yer almaları da ustalar tarafından bir başka problem olarak görülmüştür. Katılımcıların bu konuda temel yargılarının köklü bir geçmişe sahip bastonculuğun ciddiyetten uzak yapılmaya başlanması ve mesleğin geleceğini riske atılması biçiminde iki farklı düşünceyle şekillendiği görülmektedir. Buradan bir anlam çıkarsaması yapıldığında kuşkusuz ustaların kast etmiş oldukları temel bağlamın işin tarihsel belleğinden kopuşuna gönderme yapmaktır. Böylece yaptığı işin bilincinde olmayan işçilik durumunun ortaya çıkışı söz konusudur. Burada bastonun materyalleştiğini ifade etmek yerin olacaktır. 
Burada materyalleşmeden kasıt, bastonun tüketim toplumuna entegre edilmesi halidir. Bu bağlamda (K4)'ün “Şimdi herkes usta olabiliyor. Herhangi bir belge veya ustalığı olmadan usta olabiliyor ve dükkân açabiliyor. Belgesiz ustaların sayısı oldukça fazla meslek içinde karşılaştığımız en önemli sorun bu” aktarımı, (K10)'un ise "Oldu. Makineleşmeye karşı direnmek zorunda kaldık. Geleneksel şekilde baston yapmaya çalıştık ama makineleşmenin önüne geçemedik. Gerekli reklamın yapılmaması ve insanların el sanatına değerinin az olması gibi sorunlardı" şeklinde aktarımı dikkate değer bulunmuştur.

\subsection{Mesleği İcra Nedenleri}

Devrek bulunduğu bölge itibariyle ormanlar ve ağaçlar bakımından oldukça zengin bir orman örtüsüne sahiptir. Baston yapımında kullanılan materyallerin en başında gelen kızılcık ağacı, Devrek'te oldukça fazladır. Kızılcık ağacının dalının işlenmesi ve baston yapılacak hale getirilmesi uzun bir zaman istemektedir. Devrek sakinlerinin madencilik dışında çok fazla yaygın iş olanağının olmaması ve bastonculuğun babadan oğula geçen geleneksel bir meslek olması, Katılımcılar için bastonculuğun kaybolmasının şimdi ve gelecekte önemli bir sorun olarak belireceğini ileri sürmek mümkündür. $\mathrm{Bu}$ kapsamda katılımclara yöneltilen bir başka soru "Bu mesleği sevdiğiniz için mi yapıyorsunuz yoksa çalışabilecek başka alanınız olmadığı için mi yapıyorsunuz?" olmuştur. Baston ustalarının bu meslek alanında neden çalıştıkları ve yaptıkları işten tatmin olup olmadıkları noktasına açıklık getirme kaygısıyla sorulan bu soruda mesleğin eski değerini kaybedişinin görünürlüğü daha yoğun hissedilmiştir. Araştırma kapsamında yöneltilen soruya (K1)'in değerlendirmesi, "ilkokul 5. Sinıftan beri bu işle uğraşıyorum. Kastamonu'da el işçiliği eğitimi aldıktan sonra 1987'de Devrek'e geldim ve bu işe başladım ve bu işi severek yapıyorum" şeklinde iken, bir diğer katılımcı şu şekilde yanıt vermiştir. 
"Başlangıçta ne olduğunu bilmeden halk eğitimde kursa katıldım. Mecburiyetten ustanın yanında çalışmaya başladım. 6 ay süre sonra dükkân açtı. Standart Devrek bastonu yapmaktan sıkılıyorum. Fakat ilgimi çeken șeyler olduğunda zevkle yapıyorum. Başka alanım olmadiğı için." (K6)

Bastonun kültürel bellekte sürdürülebilirliği ve geleneksel meslek formu olarak devam ettirilmesi ustaların birincil kaygısıdır. Mesleği yaşatmaya çalışan ustalar için bastonculuk baba ve ata mirası ya da babadan kalma meslek özelliği taşımaktadır. Küçükken yapmak istediği mesleği yapamayan ve el yatkınlığı olduğu için bastonculuk işine yoğunlaşan ustaların varlığı da ayrıca dikkat çekmektedir. $\mathrm{Bu}$ bağlamda (K4)'ün bastona ve bastonculuğa yüklediği anlam "çocukluk zamanımda ressam olmak istedim. El yatkınlığım olduğu için bu işe bastonculuğa başlamaya karar verdim" şeklinde olmuştur. Diğer bir katılımcı ise bastonculuğa "En başta mecburi başladım. Sonradan öğrendikçe sevdim. Dedem marangozdu başka bir meslek hiçbir zaman düşünmedim. Dükkânımın devamını elimden geldiğince sağlayacağım" (K7) şeklinde bir anlam yüklemesi yapmıştır.

Devrek'te bastonculuk önemli bir uğraştır. Kayboluyor ancak ustalar mesleğe olan aidiyetliklerini sürdürmeye devam etmektedirler. Makineleşmenin insanlara ucuz ve standart bastonlar sunmasıyla maddi-manevi her türlü zarara maruz kalan bastonu ve bastonculuğu meslek olarak sürdürecek olan da bahsi geçen aidiyetlik hissidir. İși benimsemenin ve isteyerek yapmanın kuşkusuz ustalar üzerine ekonomik baskı oluşturduğunu da ifade etmek gerekir. Dolayısıyla ekonomik baskı, bastonculuğun geçimlik bir iş olarak sürdürülebilirliğinin güçleştirmektedir. Katılımcılardan ikisinin işe yüklediği anlam ve işle geliştirdikleri aidiyetlik hissininaktarımlarına şu şekilde yansıdığı görülmektedir: 
“Ben Kastamonu Ağaç İşleri Oyma ve Dekorasyon bölümünde el işçiliği ve sanatı öğrendim. Devrek'teki baston ustalarına farklı motif ve desenler öğrettim ve böylece bu iş üzerinde çalışmaya başladım" (K5).

"Sevdiğim için başladım. Çıraklıktan geldim. Başka bir meslek hiç düşünmedim geçimimi sağlayacak derecede ekmeğimi aldım bir de yeteneğimi kullandım" (K9).

Araștırmaya katılan bir başka katılımcının bastona ve bastonculuğa yüklemiş olduğu anlam ise, "bu mesleği sevdiğim için yapıyorum. Ağacı seviyorum, doğayı seviyorum başka bir meslek yaptım, ikisini birlikte yaptım ama tercihim bastonculuk oldu" (K8) şeklinde karşımıza çıkmıştır. İktisat Fakültesi'nde öğrenim görüp baba mesleğini devam ettirmek için başka bir iş yapmayan diğer bir katılımcı ise yaptıkları işi şu ifadelerle anlamlandırmıştır:

"Tabi ki bu mesleği sevdiğim için yapıyorum. Baba mesleği, babadan kalan mirasın devamı niteliğinde olduğu için bu mesleği severek devam ettiriyorum. Ayrıca iktisat fakültesinden mezun oldum. Farklı bir alanda çalışma imkanımda vardı ancak ben bastonculuğu ve baston yapmayı tercih ettim." (K2)

Sanayileşme üretim alanında köklü değişimlere neden olmuştur. Değişen üretim tarzlarının etki alanının en geniş olduğu sektör olarak geleneksel meslek alanlarını göstermek mümkündür. Devrek'te yaşayan ve baba mesleği olmadığı halde bu meslekle geçimini sağlayan katılımcllardan (K3)'ün söyleminde "aslında bu meslek bize babadan kalma bir meslek değil ama Devrek'te yaşlyor olmamız bizi bu işi yapmaya mahkûm ediyor gibi bir şey" şeklinde olurken; bir diğer katılımcı (K10) ise "Mesleğe çıraklıktan başladım. Şu anda usta öğreticiyim. Yaptığım işi her zaman sevdim bu işsabır işi başka bir sektör düşünmedim" değerlendirmesinde bulunmuştur. Burada ortaya çıkan bağlamın iki noktada değerlendirilmesi gerekir. Bunlardan ilki geleneksel mesleklerin coğrafyayla doğrudan ilişkisi vardır. Coğrafya, fiziksel ve doğal özellikleriyle topluluk üyelerine 
sunduğu imkanlarla onların hangi mesleklerle kendilerini şekillendireceğine etkide bulunmaktadır. Diğer bir nokta ise herhangi bir ustanın işiyle "tutku" ekseninde geliştirilen aidiyetlik bağı oldukça güçlü dışa yansımakta, bastonu ekonomik meta olmaktan çıkmasına kaynaklık etmektedir.

\subsection{Devrek Bastonunun Tanınılırlığı}

Baston yapımının tarihi çok uzun yıllar öncesine dayanmaktadır. Mitolojik döneme kadar uzanan baston tarihi günümüze kadar ulaşmayı başarmış geleneksel bir motif olarak dikkat çekmektedir. 1992 yılında dünya çapında düzenlenen bir fuara katılan Çelebi Usta, Devrek bastonunu dünyaya tanıtmış ve bu fuara katılan ilk Türk olmuştur. Devrek bastonunu özelleştiren sebepler arasında baston yapımı esnasında kullanılan malzemelerin biricikliği ve harcanan emeğin oldukça yoğun olmasıdır. Devrek bastonunu tanınır yapan temel noktaları somutlaştırma amacıyla "Devrek bastonunun bu kadar tanınmasindaki temel etken sizce ne olabilir?” sorusu katılımcılara yöneltilmiştir. Yanıtlara bakıldığında ilk olarak baston yapımında kullanılan malzemenin biricikliğine atıf yapıldığı görülmektedir. K1'in konuyla ilişkili değerlendirmesi şu şekilde olmuştur:

"Bastonun tanınmasında en önemli etkenler kızılcık ağacının dalından yapılması esnek ve dayanıklı olması, farklı model ve desenlerle özdeşleşen Devrek Bastonu altını çizerek söylüyorum; tamamen el yapımı olmasıyla bu kadar tanınmış bir ürün olarak ortaya çıkmıştır."

Bir başka katılımcı ise aynı soruya "Devrek'te yetişen ă̆acın olması, büyük ustalar bu işi başlatmış, bastonla da duyurulmuştur bu çarşının olması duyurulmasında etkili olmuştur"(K7) şeklinde yanıt vermiştir. Devrek'te bulunan "Bastoncular Çarşısı" özel olarak kazandığı turistik anlamıyla dikkat çekmekle birlikte ustaları tek bir 
çatı altında topluyor olmasıyla da önemli mekandır. Ancak çarşısının turistikleşmesi, zamanla ustaların yaptıkları bastonların yanında makine ürünü bastonların da yaygınlaşmasına neden olmuştur.

Kullanılış şekli, uzun ömürlü, dayanıklı ve esnek olması Devrek bastonunu özel kılan durumlardır. Fabrika yapımı ürünlerin Türkiye'de Devrek bastonu olarak satılması bastona olan genel ilgiyi azaltmakla birlikte Devrek bastonunun ünü üzerinden makine ürünlerinin kendisini sattırdığı görülmektedir. Ancak ustaların yaptığı değerlendirmelerin en belirgin taraflarından birisi her ne kadar makine ürünü bastonların görünürlükleri artmış olsa el yapımı baston ile makine yapımı baston arasındaki farkların hala belirgin bir şekilde görülebilmektedir. Devrek genelinde de makine yapımı bastonlar satılmakta fakat el işçiliği ile yapılan bastonlar alıcısının ilgisini çekmeye devam etmektedir. Devrek bastonun biricikliğine vurgu yapması bağlamında K2'in değerlendirmesi, “Kızılcık ă̆acının dallarından yapıyor olmamız, esnek ve dayanıklı olması, işçiliğin çok önemli bir yeri olması ortaya bir anlamda sanatsal ürünlerin çıkışını sağlıyor" şeklindeyken; diğer bir katılımcının(K9)'un değerlendirmesi ise, "Eskiden olan baston ustalarının etkisiyle gelişmiştir" şeklinde olmuştur.

Zanaatkarlık becerisi eğitilmiş bir pratik olarak karşımıza çıkmaktadır. Yani el becerisi doğrudan gelen ilhamla bir ilişki halindedir. Bu bağlamda zanaatkarlığın ve el becerisinin ilhamla olan ilişkisi göz önünde bulundurulduğunda becerinin en saf halinin eğitimin bir adım önünde bulunduğunu söylemek mümkündür (Sennett, 2006, 54). Her ustanın baston üzerinde işlediği motifler ve desenler birbirinden farklı izler taşımaktadır. Ustaların bastonu hazırladığı motifler önceden tasarlanan ya da kurgulanan taslaklar olmadığı için ortaya çıkan ürün sanat eseri niteliği taşımaktadır. Konuyla ilişkili katılımcıların aktarımları Devrek bastonunun ustalarına özgün taraflarının varlığını da dikkate sunmaktadır: 
“Geçmiş zamanda ustalar doğaçlama figür oluşturmakta ve bu figürleri rüyalarında gördüklerini söylerlermiş. Aynı motifleri her ustanın yapış şekli farklıdır. Bu da Devrek bastonunun ününün artmasına ve tanınmasında katkı sağlıyor" (K3).

"Rahmetli eski Ulaştırma Bakanımız Doktor Veysel Atasoy'un büyük katkıları olmuştur halk eğitimde açılan kurslardan mezun olan öğrenciler şu anda bu meslekten ekmeklerini kazanıyor bu ağaç çok dayanıklı ve esnektir rengi beyazdır işlemesi baklava ve yılandır" (K10).

\subsection{Makine Bastonu Öldürdü mü?}

Sanayileşmeyle birlikte makinelerde üretim yapılmaya başlanması üretim tarzlarının yaşamış olduğu en büyük devrim olarak nitelendirilebilir. Seri üretim tarzı hayatın pek çok noktasında kolaylıklar sağlamış ve çok kısa süre içinde çok sayıda ürünün piyasaya sürülmesi sanayileşme çağında gerçekleşmiştir.Ancak makineleşmenin olumsuz tarafları da çok net bir şekilde görülmektedir. Özellikle zanaat olarak adlandırılan ve el emeğine dayalı üretim tarzları bu alandan olumsuz yönde etkilenmiştir. Modern zamanlara gelindiğinde el emeğinin ekonomik tarihi incelendiğinde makineleşme çoğu zaman dost olarak görünüp sona gelindiği zaman ise el emeğinin düşmanı olarak sona ermiştir (Sennett, 2006, 108). Bu bağlamda Devrek'te bastonculuk yapan ustalara sanayileşmenin el yapımı ürünlere nasıl etki ettiği, mesleğin sanayi öncesi dinamiklerinden uzak kalıp kalmadığı ve bastona olan ilginin son durumunun ne olduğu alt kaygllarının tespit edilmesi amacıyla "Sanayileşmeyle birlikte el yapımı ürünlere olan duyarlılıkta sizce azalma oldu mu" sorusu yöneltilmiştir. Böylece Devrek bastonunun günümüzdeki durumu açıklığa kavuşturulmak hedeflenmiştir.

Katılımcıların aktarımlarına bakıldığında ilk dikkat çeken nokta bastondan anlayan, el işi ile makine işi arasındaki ayrımı yapabilen 
gerçek bastonseverlerin gerçek Devrek bastonuna hala duyarlı oldukları durumudur. Bu durumu katılımclardan birisi "seri üretim fazla olunca işi bilen insanlar el yapımını arıyorlar ve talep bazı zamanlarda artıyor" (K7) şeklinde betimlemiştir. Bir diğer katılımcı ise makineleşmenin baston üzerinde yarattığı olumsuzluğa vurgu yapmıştır:

"Tabi ki sanayi ve makine işin içine girince el yapımı bastona olan ilgi ücretinden kaynaklı azalmaya başladı. Bastonlara olan ilgi hem sanayi etkisi hem de baston üreticilerinin maddiyata önem vermesinden dolayı azalmıştır"(K4).

Sanayileşmeyle değişen üretim formları beraberinde rekabeti de getirmektedir. Sennett'e (2006) göre makine dost görünümlü bir düşman niteliği taşıdığı için makineyle yapılan baston sayısıyla, el ile yapılan baston sayısı arasında sayısal farklar oluşmakta bu durum da makineleşmenin el emeğinin önünde haksız rekabeti ortaya çıkarmaktadır. Eşit koşullar altında verilen mücadele, kıstasının dışında kalmaktadır. Bu bağlamda katılımcıların birinin(K1) aktarımı "sanayi sanatı öldürüyor. Seri ve aynı tarz üretim ortaya çıkıyor ve farklı olan hiçbir ürün, desen ve motif fabrikalarda kullanılmıyor. Seri dağıtım rekabeti zorlaştırıyor" şeklinde olmuştur. Diğer bir katılımcı (K8) "evet oldu çünkü bastonumuza atalarımızdan gelen değerimize kimse sahip çıkmıyor, değeri bilinmiyor" şeklinde bir değerlendirme yapmıştır. K1'in değerlendirmesini destekler nitelikte değerlendirme yapan K2'nin düşünceleri ise “Zanaattan sanata doğru bir yolculuk diyebiliriz. Lakin sanayileşme ve bu işi çok büyük pazarlara çeken Çin ile mücadele içinde olmamız çok da mümkün bir durum olmuyor" şeklinde olmuştur. Sanat yerini rekabet anlayışına bırakmakta ve geleneksellik özelliği taşıyan bu mesleki formun sonunu sanayileşme getirmektedir. Seri üretime karşı koyamayan baston ustaları kendi yaptıkları işten keyif almamaya başlamaktadır. Ustaların kendi iç dinamizmlerinin kaybolması sanayileşmenin el sanatlarına verdiği zarar kadar büyük bir zarardır. Bu bağlamda baston ustası olan K3'ün aktarımı şu şekilde olmuştur: 
"El yapımı ürünlere olan azalmanın aslında sanayileşme etkisiyle değil de ustaların kendi içinde olan kopukluklarından kaynaklı olduğunu söyleyebilirim. Herkes birbirini rakip görmeye başladı̆̆ı için nitelikli ürün çıkarılamıyor."

\subsection{Kuşaklararası Aktarımda Baston}

Sanayileşme geleneksel meslekleri olumsuz yönde etkilemiştir. Geleneksellik bağlamında kültürel temelleri çok uzun süre öncesine dayanan Devrek bastonculuğu seri üretim tarzına karşı direncini kaybetmiştir. Maddi olarak beklentileri karşılayamaz duruma gelen bastonculuk hem usta kaybetmeye hem de mesleğin devamını sağlayacak nitelikte çırak yetiştiremez duruma gelmiştir. Baston kültürü eski popülaritesini kaybetmeye başlamıştır. Mülakat sürecinde ustalara "Devrek baston yapımının kültürel olarak devamı gelir mi?" sorusu yöneltilerek bastonculuğun gelecek yıllardaki konumunun ne olacağının sonucuna ulaşmak hedeflenmiştir. Katılımcılara yöneltilen soruya verilen yanıtlara bakıldığında genel yargı mesleğin yaşamın kıyısında olduğu vardır. Konuyla ilgili katılımcılardan birisi (K6) "33 yıldır devam eden bir şey daha fazla da devam edecektir gelecek nesillere ulaşacaktır" değerlendirmesini yaparak, bir diğer ise "bastonculuğu bir tür ă̆aç oymacılı̆̆ı olarak görebiliriz. Insanların ağaç oymacılığına olan merakı devam ettikçe bastonculukta devamlılığını koruyacaktır"(K2) şeklinde öngörüsünü belirterek mesleğin devam edeceğine vurgu yapmıştır. bir diğer katılımcı ise bu konuda oldukça karamsardır:

"Devrek bastonu hem kültürel hem de geleneksel olarak gelecek nesillere ulaşamaz. En fazla 10 yıl içinde de meslek tamamen bitecek ve bunun nedeni de yetişecek çırağın olmayıșı her şeyin maddi değerlere dönmüş olmasıdır"(K5).

Bastonculuk mesleğinin dayandığı tarihsellik ve kültürel kökler dikkate alındığında çok az sayıda usta tarafından devam edeceği ileri 
sürüldüğü görülmektedir. Bölgenin coğrafi konumu, iş çeşitliliğin sınırlı olması ve Devrek'in bastonla özdeşleşmiş olması mesleğin gelecekte kısmen de olsa süreceği iddiasını güçlendirmektedir. Bastonun geleceği önünde engel görülen durumların katılımcıların aktarımlardan hareketle şu şekilde görselleştirmek mümkündür.

Tablo 2. Bastonculukla İlgili Sorunların Algılanma Durumu

\begin{tabular}{|c|c|}
\hline \multirow[t]{4}{*}{ Ekonomik Sorunlar } & Baston yapımının maliyetli olması \\
\hline & $\begin{array}{l}\text { Yap1lan ürünün maddi anlamda } \\
\text { beklentiyi karş1layamamas1 }\end{array}$ \\
\hline & $\begin{array}{l}\text { Seri üretimin el işçiliğine tercih } \\
\text { edilmesi }\end{array}$ \\
\hline & $\begin{array}{l}\text { Ucuz malzemelerle üretim yapılmaya } \\
\text { çalıșılması }\end{array}$ \\
\hline \multirow[t]{3}{*}{ Kaynak Temini } & $\begin{array}{l}\text { Kaliteli ağaç dalını bulmanın zor } \\
\text { olması }\end{array}$ \\
\hline & $\begin{array}{l}\text { Kızılcık ağacıyla uğraşmanın } \\
\text { zahmetli olması }\end{array}$ \\
\hline & $\begin{array}{l}\text { Ormancılık ve ağaç işlerine olan } \\
\text { ilginin azalması }\end{array}$ \\
\hline \multirow[t]{4}{*}{ Toplumsal Sorunlar } & Emeğin geri planda bırakılmas1 \\
\hline & Evde baston yapımının devam etmesi \\
\hline & $\begin{array}{l}\text { Belgesiz ve vasıfsız ustaların artı̧̧ } \\
\text { göstermesi }\end{array}$ \\
\hline & Yetişecek çırakların bulunamaması \\
\hline \multirow[t]{4}{*}{$\begin{array}{l}\text { Devlet Desteği ile İlgili } \\
\text { Sorunlar }\end{array}$} & $\begin{array}{l}\text { Fabrikasyon ürünlere verilen desteğin } \\
\text { sanatç1lara verilmiyor olması }\end{array}$ \\
\hline & Ustalara gereken değerin verilmemesi \\
\hline & Yetkililerin ustalara sahip çıkmaması \\
\hline & Projelerin ihtiyaçları karşılayamaması \\
\hline
\end{tabular}

Baston kültürünü silikleștiren ve bu mesleği yaşamın kıyısına getiren faktörlerin başında temelde sanayileşme olsa da mesleği icra eden ustaların maddi kazancının yüksek olması nedeniyle el yapımı bastonu bırakıp makine ürünleriyle ilgilenmeleri bir paradoks olarak görülmüştür. Bu bağlamda (K1)'in ve (K7)'nin değerlendirmesi söyleme şu şekilde yansımıştır: 
"Bu meslek hayatta ölmez bir meslek. Sonu gelmez bir meslek. Mesleği biz bastoncular öldürüyoruz. El işçiliğini biraktık. Fabrikasyona döndük Tabi ki usta-çırak ilişkisi de sona doğru gelmeye başladığı için bastonculuk da kaybolmaya başladı."

"Devamı gelir, kültürel olaylar artarsa devamı sağlanabilir çırakların yetişmeye başlaması gerekiyor tabii ki" değerlendirmesini yaparak mesleğin kültürel anlamda devam edeceğini ifade etmiştir.

\section{Sonuç ve Tartışma}

Toplumların gelenekleri ve kültürlerini yansıtan en önemli yapı taşlarından birisi el sanatlarıdır. Devrek Bastonculuğu da bu noktada geçmişten günümüze kadar ulaşmış önemli bir değer olarak karşımıza çıkmaktadır. Devrek Bastonunu önemli kılan, bastonu üreten ustaların sadece kendilerine has yöntemler ve desenler kullanıyor oluşundan kaynaklanmaktadır. Kültürel miras açısından baston üreticiliği ve baston üretiminin devamı geçmişle olan bağlantının kopmaması ve kültürel belleğin devamını sağlamak açısından oldukça önemlidir. Devrek Bastonculuğunun tarihi 18. Yüzyıla kadar dayanmakla birlikte günümüze kadar ulaşma başarısını da göstermiştir. Kendine özgü motif ve desenleri ile dünya çapında tanınır bir ürün olarak da karşımıza çıkmaktadır. Küreselleşmenin hâkim olduğu piyasa içerisinde kültürel miras, kültürel değerler kendini koruyamaz duruma gelmiştir. Sanayileşmenin çalışma hayatını dönüştürdüğü biçimler de küreselleşmenin köşe tutucu unsurları olarak belirmektedir. Böylece makine ürünlerinin kolay satılabilir ve daha fazla talep ediliyor olması el emeğiyle yapılan ürünleri de piyasa dışında bırakmaktadır. Ayrıca mesleği öğreten ustaların ölmesiyle birlikte Devrek bastonculuğu kültürel geleneğini devam ettirme konusunda da gerileme süreci içerisinde girmiştir Baston ustalarının sanayileşmeye gösterdikleri direncin yetersiz kalması, bastonculuğun kaybolmaya 
yüz tutan bir mesleki kod haline gelişini hızlandırmıştır. $\mathrm{Bu}$ çalışmada "Devrek Bastonunun" sanayileşmenin etkisiyle yaşamış olduğu dönüşümü baston ustalarının nasıl değerlendirdiğini çözümlemek amaçlanmıştır. Bu bağlamda elde edilen verilerden ulaşılan sonuçları şu şekilde sıralamak mümkündür:

- Devrek bastonu, geleneksel toplumun modern kapitalist sistem karşısında tutunamayışını deneyimlemektedir.

- Makinenin gücü arttıkça, insanlardaki "daha çok kazanma" güdüsü artmakta, el yapımı baston yerini fabrika ürününe bırakmaktadır.

- Büyük marketlerde düşük fiyatlarda Devrek bastonu etiketiyle satılan baston, tüketim toplumunun gündelik hayatı standartlaşmasının özel bir hikayesini sunmaktadır. Böylece tüketicilerin talebine eşlik eden bir üretim süreci, Devrek bastonunu sıradanlaştırmaktadır.

- Materyal temininin maliyet ve sabır gerektirmesi; bunun artık bir külfet olarak değerlendirilmesi. Bastonun geleneksel hikayesi kızılcık ağacının peşinde olmaktır. Hikaye, "kızılcı̆̆ı aramak, bulmak, dokunmak, onu atölyeye getirmek, hazırlamak, bekletmek, firınlamak, duvara asmak ve üzerine işlenecek motif ilhamının gelmesini beklemek" parçalarından oluşur. Makineleşme, Devrek bastonuna ait hikayenin özgünlüğünü ortadan kaldırmıştır.

- Özellikle yeni kuşak baston yapıcılar işi atölye dışına çıkarttılar, fabrika işi üretime dönüştürdüler ya da atölyelerine makine getirdiler. Bastonda kullanılan kızılcık ağacı yerini “oduna” bıraktı. Esnekliğini kaybeden ve makineden çıktığında bastondan ziyade ucuz ve kirılgan bir tahtaya dönüşmüştür. Odunun bastona dönüşmesi Devrek bastonunun kalıcı, uzun ömürlü ve esnek yapısını ortadan kaldırmıştır. Daha ciddi bir sorun ise kızılcık ağacına ilham veren ona dokunan ve onu işleyen ustanın pratiklerini yok etmiştir. Böylece bastonun nesneleşmesi ya da şeyleşmesine eşlik eden bir ölümün kıyısında öyküsü başlamıştır. Kızılcık ağacının peşindelik, tahtalaşmıştır. 
- Devrek bastonu ile ilgili problemler sıralandığında kuşkusuz bastonun geleceğe taşınması konusunda dikkat çekici olan ustaların destek konusunda yalnız olduklarını ifade etmeleridir. Yalnızlık, hem devletin kurumlarıyla herhangi destekleyici bir pratikte bulunmamasına, hem de baston ustalarını bir çatı altına tutan derneğin pasif kaldığına dair yargıyla ilişkilendirilmiştir.

- Ustalarla yapılan görüşmelerde merdiven altı üretimin kendileri için ciddi bir tehdit olduğunu ortaya koydukları görülmüştür. Maliyetler artarken piyasadaki ucuz bastonların kendine yer bulmasının yaptıkları işin değersizleşmesi ve kaybolması sürecini hızlandırdığı ifade ettikleri görülmüştür.

- Geleneksel mesleklerin babadan oğula geçen yönü, çocukların baba mesleğini tercih etmemeleri ve yetiştirmek için çırak bulunamaması gibi sebeplerle ortadan kalkmıştır.

- Geçim derdinin mesleğin önüne geçmesi, bastonculuğun kaybolmasında ciddi bir sebep olarak betimlenmiştir. İşle uğraşan ustaların da kendilerine yeni iş alanları açmaya çalıştıkları görülmüştür. $\mathrm{Bu}$ durum bastonun tek iş olmaktan çıkmasına ve ustaların baston üzerindeki tutkusunun sönmesine kaynaklık etmiştir.

- Kuşkusuz Zonguldak'ın da içerisinde olduğu Batı Karadeniz Bölgesi'nin geçmişe kıyasla göç veren ve iş alanları daralan bir durumda olması, Devrek'in de kaderine terkedildiği imajını güçlendirmektedir.

Sonuç olarak bakıldığında baston üretimiyle ilgilenen ustaların resmi kurum ve kuruluşlardan yeterli desteği alamamalarından dolayı meslekte tutunmakta zorlandıkları konusunda hemfikir oldukları tespit edilmiştir. Çocuklarının işleri peşine gitmeleri mesleğin kültürel miras olmasını da kesintiye uğrattığı görülürken, bu durumun Türkiye'de diğer geleneksel mesleklerle ilgili süreçle paralel ilerlediği tespit edilmiştir. Seri ve ucuz üretimle ortaya çıkan "tahta"lar, ustaların makineye karşı dirençlerinin kırılmasına neden 
olmuştur. Ekonomik kaygıların üst düzeyde belirdiği bir gündelik hayat içerisinde bir baston ustasının "artık rüya göremiyorum" diye başladığı söylemini "eskiden rüyamda kızılcık ağaçlarını işlerdim. Rüyamda bastona işleyeceğim motifler konusunda ilhamlar gelirdi” şeklinde bitirmesi süreci özetler mahiyettedir. Yaşamın kıyısında olmaklığın iyimser bir yaklaşım olacağına istinaden Devrek bastonunun geldiği son noktayı ölümün kıyısında şeklinde tanımlamak yerinde durmaktadır. Makinenin ve neo-liberal kazanç tutkusunun bastonu fotoğrafa ve müzeye kaldıracağı, "McÇinlileşmenin" sonucu olarak dükkanlarda turistik bir nesne olarak tutacağı çok da uzak olmayan gelecektir. McÇinlileşmeye geleneksel kültürel pratiklerin mekanda tüketim toplumuyla entegre hale gelişini betimleyen materyalleşme eşlik edecektir. Materyalleşme, çağımızda kültürü bekleyen en büyük risk olarak belirmiştir.

\section{Kaynakça}

Arseven, Celal Esad. Sanat Ansiklopedisi. İstanbul: Milli Eğitim Basımevi, 1983.

Arslan, Ferhat - Çağlar, İlker- Gürbıyık, Cengiz. Kültürel Miras Kapsamında Kaybolmaya Yüz Tutmuş Geleneksel Meslekler: Turgutlu Örneği. Studies Of The Ottoman Domain. 7/13 (2017), 211-244.

Bayar, Fırat. Küreselleşme Kavramı ve Küreselleşme Sürecinde Türkiye. Ekonomik Sorunlar Dergisi 32 (2008), 25-34

Creswell, John. W. Nitel Araştırma Yöntemleri: Beş Yaklaşıma Göre Nitel Araştırma ve Nitel Araştırma Deseni. Ankara: Siyasal Kitabevi, 2013.

Çelebi, Münteka. El Sanatları ve Devlet, Kamu ve Özel Kuruluşlarla Orta Öğretimde, Üniversitede El Sanatlarına Yaklaşım ve Sorunları Sempozyumu Bildirileri, 18-20 Kasım 1992, İzmir, 
Evden Atölyeye, Atölyeden Fabrikaya Etnografik Bir Çalışma: Devrek Bastonu Örneği

Kültür Bakanlığı Yayınları, Ankara. 1994.

Çelikdönmez, Ömür. Devrek Tarihi. Ankara: Devrek Ticaret ve Sanayi Odası Yayınları, 2000.

Devrek Bastonu. Erişim 29 Şubat 2020.

http://www.devrek.gov.tr/devrek-bastonu1. 2020

Dilmaç, Oğuz. Erzurum'da Kaybolmaya Başlayan Yöresel El

Sanatları. Akdeniz Sanat Dergisi 6/11 (2013), 93-101.

Doğan, Mesut. Geçmişten Günümüze İstanbul'da Sanayileşme Süreci ve Son 10 Yıllık Gelişimi. Marmara Coğrafya Dergisi 27 (2013), 511-550

Efiloğlu, Ahmet. Insan, Kimlik, Mekan Bağlamında Zonguldak Sempozyumu. Bülent Ecevit Üniversitesi Yayınları, 2014.

Harman, Ömer Faruk. "Dinler Tarihi”. Türkiye Diyanet Vakfı İslam Ansiklopedisi. Erişim 27 Kasım 2019.

https://islamansiklopedisi.org.tr/asa\#1-dinler-tarihi

Kartarı, Asker. (2017). Nitel Düşünce ve Etnografi: Etnografik Yönteme Düşünsel Bir Yaklaşım. Moment Dergi Hacettepe Üniversitesi İletişim Fakültesi Kültürel Çalışmalar Dergisi 4/1 (2017), 207-220

Koçak, H. Teknoloji ve Toplumsal Değişme. Ayrıntı Dergisi (2016), $4 / 44$.

Koyuncu Okca, Ayșegül. Denizli'de Kaybolmaya Yüz Tutmuş Kimi Geleneksel Meslekler. Akademik Bakış Dergisi 58 (2016), 201223

Köseler, Halil. Erişim 27 Kasım 2019. Görme Özürlüler İçin Baston 
Kullanmanın Önemi ve Tarihçesi. Altı Nokta Körler Derneği Merkezi

http://www.altinokta.org.tr/yazardetay.asp?idnourun=39. 2019.

Nadas Muhlis. Türk Dünyasında Tur Kültü: Truvalılar ve Türkler. İstanbul: İnkılap Kitabevi, 1995.

Özcan, Sevil. Coğrafi İşaret Kavramı ve Devrek Bastonu Örneği, Bartın: Bartın Üniversitesi, Fen Bilimleri Enstitüsü, Yüksek Lisans Tezi, 2016.

Pakalın, Mehmet Zeki. Osmanlı Tarih Deyimleri ve Terimleri Sözlüğü. İstanbul: MEB Yayınları, 1993

Sağır, Adem. İktisadi Hayatın Değişimi ve Kayıp Mesleki Kodlar Üzerine Sosyolojik Bir Çözümleme: Zonguldak / Bartın / Karabük Örneği. The Journal of Academic Social Science Studies 48 (2016), 27-45

Sennett, Richard. Zanaatkar. İstanbul: Ayrıntı Yayınları, 2006.

Sevin Veli. Anadolu'nun Tarihi Coğrafyası. İstanbul: Türk Tarih Kurumu Yayınları, 1993.

Strangleman, Tim - Warren, Tracey. Çalışma ve Toplum çev. Fuat Man. Ankara: Nobel Yayınevi, 2015.

Şahin, Emine. Kızılcık Dalının En Zarif Hali: Devrek Bastonu. Erişim 12 Ocak 2019 https://www.ismek.ist/blog/icerik.aspx?p=1228. 2019

Talas, Mustafa - Kaya, Yaşar. Küreselleşmenin Kültürel Sonuçları. Türklük Bilimi Araştırmaları. 22 (2007), 149-162 
Evden Atölyeye, Atölyeden Fabrikaya Etnografik Bir Çalışma: Devrek Bastonu

Teke, Tuğba - Erol Çalışkan, Şerife Seher. Geçmişten Günümüze Devrek'te Bastonculuk Geleneği. Uluslararası Sosyal Araştırmalar Dergisi 11/56 (2018), 95-100

Terzi, Harun - Oltulular, Sabiha. Türkiye'de Sanayileşme ve Ekonomik Büyüme Arasındaki Nedensel İlişki. Doğuş Üniversitesi Dergisi 5 (2004), 219-226

Tuncer, Ömer. İște Anadolu. İstanbul: Arkeoloji ve Sanat Yayınları, 1993.

Yalın, İrfan. Bastonun Kültür Tarihi. Erișim 27 Kasım 2019. https://t24.com.tr/yazarlar/irfan-yalin/bastonun-kulturtarihi,24184. 2019. 
Adem SA $\breve{I R}$-Semih KURTKARA 